Article

\title{
"You're Throwing Your Life Away": Sanctioning of Early Marital Timelines by Religion and Social Class
}

\author{
Patricia Tevington \\ Sociology Department, University of Pennsylvania, Philadelphia, PA 19104, USA; E-Mail: ptev@sas.upenn.edu
}

Submitted: 30 January 2018 | Accepted: 9 March 2018 | Published: 22 June 2018

\begin{abstract}
In the midst of a shifting economic and cultural landscape, many young adults spend their twenties focused on individual achievement and self-actualization while delaying entrance into social roles such as marriage. Yet religion, particularly Evangelical Protestantism, places a high value on marriage as the legitimate context for sexuality and childbearing-which encourages earlier unions. This article, based on interviews with 87 dating, engaged, and married Evangelical young adults (aged 18 to 29), describes the social reaction to respondents' marital timelines, which are typically at younger ages than their secular peers. Two sources of strong disapproval emerge. First, secular influences from outside of these respondents' religious communities are almost unilaterally critical of early marriage plans. Second, even within religious communities, Evangelicals from middle class cultural milieus may face additional disapproval if their family formation plans are interpreted as compromising their educational goals. This article offers important insight on the intersecting roles of religion and social class in shaping the trajectories of young adults.
\end{abstract}

\section{Keywords}

Evangelical Protestantism; marriage; religion; social class; young adults

\section{Issue}

This article is part of the issue "Complex Religion: Intersections of Religion and Inequality", edited by Melissa J. Wilde (University of Pennsylvania, USA).

(C) 2018 by the author; licensee Cogitatio (Lisbon, Portugal). This article is licensed under a Creative Commons Attribution 4.0 International License (CC BY).

\section{Introduction}

Despite the changes in the demographic landscape of family life in the United States, marriage continues to be both held in high esteem and practiced widely. Embedded in these aspirations are understandings of the appropriate age, time, and sequence for the transition into marriage. Relatively little research has documented the stigma that comes from diverging from conventional adult pathways, such as in the case of early marriage.

Drawing on interviews with 87 partnered Evangelical young adults, I find that most of my respondents marry or plan to marry at younger ages compared to their nonreligious peers. This early transition to marriage is met with overt censoring from two sources. First, nonreligious communities-especially the secular peers of Evangelical young adults - react with surprise and derision to marriage in the late teens or early twenties. Second, middle class influences-even within Evangelical communities-encourage the delay of marriage until the successful completion of a bachelor's degree.

This article demonstrates that the social class and religious backgrounds of young adults generate strong social sanctions regarding marital timelines. While there is a larger cultural imperative to "wait" for marriage until later in adulthood, religious norms can inspire early unions among Evangelical Protestants. This encouragement is complicated by middle class sensibilities regarding the importance of educational credentials.

\section{Literature Review}

Three bodies of literature are crucial to mapping out the messages that young adults receive and adopt about the appropriate timing of marriage. First, I review the research on youth and emerging adulthood more broadly, which proposes a life stage that prioritizes identity exploration prior to the adoption of stable adult roles, such as 
marriage. Second, I describe cultural attitudes surrounding marriage and the proper baselines for entry into the union. Finally, I review research on early marriage, its predictors, and its consequences.

\subsection{Changes in the Transition to Adulthood}

Adolescence has long been acknowledged by developmental psychologists as a period of trying on roles, exploring identity, and rebelling against authority before becoming incorporated into adult society (Erikson, 1998). Historically, the achievement of the sociological milestones of adulthood-finishing one's education, leaving the parental home, establishing financial independence, marrying, and becoming a parent-were accomplished following adolescence, typically by the early twenties and roughly in the aforementioned sequence (Settersten, Furstenberg, \& Rumbaut, 2005). In the past several decades, the transition between adolescence and adulthood has become extended and complicated.

Reflecting on the increasingly vocal and rebellious young adults in college and in the hippie generation, Erikson (1970) postulated that these youth were engaging in a prolonged identity exploration and rejection of role fulfillment in adulthood. Other researchers describe the time period of the twenties as "post-adolescence", which is characterized by social independence but continued economic dependence (Richter, 1994). To varying extents, young adults during this period may be rejecting historic notions of adult status (Maguire, Ball, \& MacRae, 2001).

Some scholars see this as not just a lengthening of a transition but the unveiling of a fundamentally distinct life stage. Developmental psychologist Jeffrey Arnett $(1998,2006)$ characterizes the time between adolescence and full adulthood as a phase in and of itself. "Emerging adulthood", according to Arnett (2006), is a unique period in the life course where those in their late teens through their late twenties are in unsettled positions. The distinctive features of this life stage are fivefold: emerging adults feel "in-between" adolescence and adulthood, they are focused on themselves, they lack stability and are highly mobile in educational, career, and romantic pursuits, they engage in identity exploration, and they are focused on the existence of options and possibilities (Arnett, 1998, 2006).

Some psychologists object to the notion of emerging adulthood as a generalizable stage (Arnett, Kloep, Hendry, \& Tanner, 2010). Moreover, sociologists have taken issue with Arnett's characterization of emerging adulthood as universally applicable among young people in the developed world. In particular, the notion of young adults who take a decade to engage in highly individualistic and largely unencumbered explorations presumes a level of privilege only available to middle class persons (Berzin \& De Marco, 2010; Côté, 2014; Furstenberg, 2008; Silva, 2016; Swartz, 2008). ${ }^{1}$
Nevertheless, emerging adulthood seems to characterize at least a substantial portion of the young adult population in the United States. Given the emphasis on individual achievement and identity exploration, it is not surprising that romantic relationships during this life stage are typically less committed than they might have been in generations past. Researchers find that emerging adults are generally more preoccupied with career advancement than romantic relationships (Ranta, Dietrich, \& Salmela-Aro, 2014). Likewise, while romantic relationships still occur in young adulthood, traditional dating competes with more casual sexual arrangements, such as the hook-up culture (Bogle, 2008; Claxton $\&$ van Dulmen, 2013). These types of arrangements affect future family formation outcomes, with noncommitted sexual relationships in late adolescence being predictive of cohabitation but not marriage (Raley, Crissey, \& Muller, 2007).

\subsection{Attitudes towards Marriage}

Like adulthood, the institution of marriage has undergone tremendous change in in the last half-century. In the midst of a changing schedule of adulthood, a transformed economy, and new cultural and sexual norms, marriage has seen an overall decline, a delay in its entry, and a widening of class and racial gaps (Cherlin, 2010a). Attitudes have also shifted to allow for more flexibility and personal autonomy in family arrangements (Thornton \& Young-DeMarco, 2001).

Despite these changes, the institution of marriage is far from extinct. While the share of married adults in the United States has declined significantly, it is still half of the adult (aged 18 and older) population (Cohn, Passel, Wang, \& Livingston, 2011). Studies find that the majority of both young men and young women desire to marry and have children (Erchull, Liss, Axelson, Staebell, \& Askari, 2010; Kaufman, 2005), and most women are, indeed, projected to marry at least once in their lifetime (Goldstein \& Kenney, 2001). Finally, most never-married adults would still like to marry (Pew Research Center, 2014).

Even among populations where marriage is less common, marriage is held as an ideal. For instance, Edin and Kefalas (2005) document that their respondents, who were poor, urban, unwed mothers, held off on marriage not out of a disdain for the institution but because they did not believe they had achieved the necessary criteria for marriage readiness. Likewise, Smock, Manning, and Porter's (2005) cohabiting respondents reported plans to get married but were hampered by financial insecurity.

Indeed, to understand young adults plans' for family formation, the notion of barriers to marriage is key. Andrew Cherlin (2010b) argues that marriage is now understood as an individual achievement or accomplishment. Rather than a functional economic arrangement (Becker, 1993), marriage signals to the rest of the world that an individual has acquired a number of important baselines

\footnotetext{
${ }^{1}$ See Arnett (2016) for a response to these criticisms
} 
to attract a spouse and settle down into a stable adult relationship (Cherlin, 2010b).

Research on young adults confirms that most conceptualize marriage as something to be prepared for and ultimately achieved. Carroll et al. (2009) report that emerging adults consider the process of becoming "marriage ready" to be a largely personal transition that is distinct from-and typically occurs after-subjective adulthood is achieved. Willoughby and Hall (2015) describe three marital paradigms among young adults: the enthusiasts, the delayers, and the hesitants. The majority of respondents in their sample were "hesitant" towards marriage. That is, while they held a high opinion of marriage, they intended to wait until an appropriate age and baselines had been met. In contrast, the remainder of respondents were enthusiasts-who embraced the institution of marriage and were more likely to anticipate a younger age at marriage and support traditional gender rolesor were delayers-who expressed lower opinions about marriage and higher desires to delay or avoid marriage entirely. Likewise, Kefalas and colleagues identified two attitudes towards marriage among their qualitative sample of young adults (Kefalas, Furstenberg, Carr, \& Napolitano, 2011). "Marriage planners" dominated their sample and were described as having a high respect for marriage but a belief that it must be realized only after various milestones had been met. In contrast, a minority of "marriage naturalists" considered marriage to be simply an expected next step in a relationship.

Yet, this research is largely restricted to the opinions of young adults themselves, while overlooking how families, peer groups, and social networks respond to these unions. $^{2}$ The appropriate baselines and timelines for marriage vary within different communities and taboo unions are likely subject to negative social response. This study offers important insight on how young adults weigh influences about the appropriate timing of marriage, particularly among those that marry at younger ages than the norm.

\subsection{Early Marriage in the United States}

While marriage rates have been on the decline in the United States, this is largely attributable to an overall delay in marriage (Pew Research Center, 2014). The median age at marriage in the United States in 2011 was 29 for men and 27 for women-a significant jump from ages 23 and 20, respectively, in 1960 (Copen, Daniels, Vespa, \& Mosher, 2012). Emerging adults are marrying towards the end of their emerging adulthood, as a whole.

Yet, a not insignificant number of young adults marry still at relatively young ages. Specifically, $24 \%$ of young women and $16 \%$ of young men marry before age 23 (Uecker \& Stokes, 2008). Early marriage is predicted by a number of factors. It is more likely to occur in the Southern part of the United States and in rural areas (Kefalas et al., 2011; McLaughlin, Lichter, \& Johnston, 1993;
Uecker \& Stokes, 2008). Additionally, while less likely to marry overall, young adults from lower social class backgrounds are more likely to tie the knot at relatively younger ages than their more privileged peers (Bramlett \& Mosher, 2002; Uecker \& Stokes, 2008).

Marriage is increasingly the domain of the advantaged, such that women with bachelor's degree are now more likely to marry than their peers with less education (Goldstein \& Kenney, 2001). However, while marital unions and childbearing occur at later ages for educated men and women (Martin, 2004), childbearing is often not postponed (and occurs outside of marriage) for those without a college degree (Hymowitz, Carroll, Wilcox, \& Kaye, 2013). On the other hand, the causal arrow can also point the opposite direction-women who enter into marriage and childbearing at early ages see decreased educational attainment (Fitzgerald \& Glass, 2008; Glass \& Fitzgerald, 2012). In addition, early marriage is associated with a higher risk of divorce (Booth \& Edwards, 1985; Lehrer, 2008; Raley \& Bumpass, 2003), although marriage past the mid-twenties is associated with less divorce but also lower quality and satisfaction (Glenn, Uecker, \& Love, 2010).

Age at marriage is also strongly predicted by both religious affiliation and individual religiosity. Religious traditions such as Evangelical Protestantism and Mormonism produce higher proportions of early married young adults than traditions such as Catholicism and Judaism (Rendon, Xu, Denton, \& Bartkowski, 2014; Uecker, 2014; Xu, Hudspeth, \& Bartkowski, 2005). This may be attributed to the messages embedded in these communities about the importance of sexual purity, traditional gender norms, and childbearing. In addition, individual piety is also related to early marriage. Young adults who attend religious services frequently and express higher religious commitment are more likely to marry rather than cohabitate (Thornton, 1985; Thornton, Axinn, \& Hill, 1992) and are more likely to marry young (Uecker, 2014).

The work reviewed above provides a strong overview of the landscape of early marriage. What the literature is lacking is a more complete understanding of the context of early marriages and the experiences of young adults during this transition. Whether these unions are met with approval, disapproval, or neutrality from outside persons is essential for understanding the experiences of these early marriages as well as the of the reasoning behind marriage timelines.

Indeed, while marriage is still normative for the middle class, the baselines to marriage have been extended. Educational homogeneity has increased in marriage (Kalmijn, 1991) and both men and women are expected to be financial contributors to their union (Sweeney, 2002). Thus, wedding before socially-classed milestones have been reached may be met with resistance. Likewise, though religion continues to influence marriage markets for young adults (McClendon, 2016), affiliation with institutional religion declines dur-

\footnotetext{
${ }^{2}$ For an exception to this see Willoughby, Carroll, Vitas, \& Hill (2011).
} 
ing young adulthood (Smith \& Snell, 2009). Following distinctive marriage pathways may set highly religious young adults apart from their peers and invite criticism.

\section{Methodology and Data}

This article draws on research conducted for a larger project, which explored the family and relationship pathways of Evangelical young adults. This project sought to explore how social class and religion inform understandings of romantic relationships and decisions about marriage. In the present article, I focus on the following research question: how does the social context of Evangelical young adults encourage or discourage early union formation?

I interviewed 87 partnered and religiously active Evangelicals aged 18 to 29 . About half of the sample was already married (42 respondents), typically having wed before they turned 25 . The remainder of the sample was mostly composed of respondents who were engaged to be married or were actively planning marriage with their current dating partner.

Because I was interested in the messages that religious individuals received, I focused on a particular religious tradition-Evangelical Protestantism (Steensland et al., 2000)-and only analyzed respondents who were themselves religiously active. Thus, I recruited from religious environments. I attended churches and bible studies and solicited contacts through pastors, ministry groups, and snowball sampling of prior respondents.

Respondents were recruited as individuals, but I always tried to interview both partners in a couple. As a result, 60 respondents also have their partner in the sample. In other words, of the 87 respondents, there are 30 complete couples represented and an additional 27 respondents who were part of a couple but whose partner was not able to be interviewed.

The majority of the sample hails from a middle class background ( 56 out of 87 respondents)-understood as having at least one parent with a bachelor's degree and professional or supervisory job (Lareau, 2011)-while the remainder hail from working class roots (31 out of 87 respondents). Most respondents were white, although 5 respondents identified as black, 5 as Latino, 2 as Asian, and 2 as biracial.

With a few exceptions, interviews were conducted in person and one-on-one with a respondent. The interviews were semi-structured, with questions probing respondents' family backgrounds, relationship trajectories, and religious beliefs. Most interviews were between 60 to 90 minutes in length and respondents received $\$ 20$ stipends in thanks for their time. The interviews were digitally recorded and then transcribed verbatim. After each interview, I wrote detailed field notes describing what transpired during the meeting and the overall interaction with the respondent.

Transcripts and field notes were coded thematically using the qualitative data analysis software Atlas.ti. After reading through the transcripts, I generated an ini- tial code list that captured emergent themes in the interviews. After completing this analysis, I generated additional codes to draw out more specific themes and divergences. For example, the code "outside reaction to relationships" captured any and all discussion of opinions about the respondent's romantic relationship. This theme was further developed in the second round of coding, where I added a code entitled "pressure not to marry", which specifically focused on stigma surrounding early marriage timelines.

Interviewing only currently partnered young adults limited the ability to analyze the effect of negative sanctioning on relationship outcomes. In other words, I did not have access to respondents' whose relationships were disrupted by censoring. By and large, my respondents were already married or were reportedly on track to marry at early ages. That these respondents still reported negative feedback on their marital trajectories suggests that these findings are perhaps conservative, if higher rates of censoring led to the dissolution of unions not captured in the sample.

\section{Findings}

There were two distinct sources of stigma that respondents who married early or were on track to marry early faced. Most respondents reported some degree of resistance from nonreligious influences. In this case, marriage was understood as conflicting with a larger cultural understanding of emerging adulthood, which prioritizes self-discovery, exploration, and choice.

Secondly, respondents from middle class cultural milieus faced additional pushback for their early marriage plans if they had not yet acquired important cultural baselines, particularly a bachelor's degree. Importantly, this pushback occurred even among co-religionists, who did not disapprove of early marriage in and of itself but considered it foolish to advance to this stage without first acquiring a college degree.

\subsection{Secular Emerging Adulthood Narratives and Early Marriage}

The first source of sanctioning towards early marriage emerged among the secular world. That is, early marriage conflicted with widely held understandings of the purposes and pursuits of early adulthood, which were often distinct from religious priorities. In this case, respondents faced surprise, skepticism, or criticism at the pacing of their romantic relationships from those outside their religious communities. This pushback was typically articulated by non-Evangelical peers of respondents. To a lesser degree, some respondents faced similar stigma in more public spaces, where persons unacquainted with respondents were taken aback by their young ages and engaged or married status.

Romantic relationships in respondents' religious communities followed distinctive courtship norms. 
While churches and couples might differ on the specifics, most considered casual dating to be inappropriaterelationships were intended to be intentional, exclusive, and committed. Sexual purity was also highly prized and so relationships were encouraged to be chaste. The combination of these emphases meant that dating relationships were typically described by respondents as "serious" and assumed to be pre-marital in nature. In turn, relationships progressed relatively quickly and culminated in marriage at young ages, usually in the late teens or early twenties.

It was common for Evangelical respondents to explain that there were people in their lives that had gotten married young - such as siblings, friends, or acquaintances at church or at school. However, these norms stand out against the larger culture, where the age at marriage is rising (Copen et al., 2012) and traditional dating competes with casual sexual arrangements (Claxton $\&$ van Dulmen, 2013). This was particularly the case when respondents described the "pace" of their romantic relationships to their secular peers. That they were participating in exclusive, often nonsexual and non-cohabiting relationships, prior to marriage was unusual-especially in the urban Northeast, where this study was conducted. ${ }^{3}$ This relationship norm meant that respondents also married much earlier than their secular peers. Oftentimes, this was exemplified by respondents comparing the trajectories of different groups of their friends.

Matthew, ${ }^{4}$ a 24 -year-old middle class white man who had married the previous year, described how his secular friends from high school followed a different marital timeline compared to his Evangelical friends. Matthew said:

[Compared to] high school friends, [I married] early. Most of them, they have a significant other, marriage isn't a conversation they talk about....But [my wife] had one friend who got married [at] 23 and one got married two weeks ago. So they're our only two married friends from high school....College friends, of my friends, no-like, one of them is married now, one is getting married next year. But it wasn't weird that we got married, lots of people did coming out of a Christian college, but my friends didn't. And then current friends, because we're friends with a lot of people from our church and we're friends with a lot of people who are [parachurch organization] volunteers for us and stuff, most of our friends are married.

Robin, a 26-year-old middle class white woman who married at 21 , encountered strong opposition from nonreligious friends who were following a different trajectory than her. In particular, she noted her (nominally Catholic) best friend's distress when Robin shared the news of her upcoming nuptials. She explained:
[My best friend] just took it really hard. Like, 'You're throwing your life away'. Like, 'Why are you doing this? There's so many more fish in the sea'. 'I like [your fiancé] but you're so young. Like, you don't have to get married right now'. Everybody else in our small little [Evangelical] subculture thought it was totally normal.

This diverging of pathways between religious and secular peers was described by other respondents as well. Rebecca, a 20-year-old white woman and community college student, had been married for about half a year when I interviewed her. The daughter of a pastor, Rebecca shared that she "fell away" from her faith in high school. She recommitted religiously after graduation and subsequently met her husband. After a brief courtship, the couple became engaged. Although people at her church also married young, Rebecca describes feeling distinct from most of her peers, who were following a very different path during this time in their lives. She explained:

Most of the people that I graduated with, they went to public universities and are still continuing their education. And I think in our generation, just the mindset of when you get married is totally different for most people. Most people don't want to get married young and they want to experience different things before they get married.

But, as mentioned earlier, not only did Evangelicals get married younger-they also approached relationships differently. Relationships were considered precursors to marriage-such that dating was intentional, and marriage was discussed as a possibility early on in the relationship (if not before). These distinct relationship norms could be jarring for those outside of the Evangelical subculture.

Luke, a 20-year-old white man, described feeling like an object of curiosity. A college student at a state university, Luke had purchased an engagement ring but not yet proposed to his long-time girlfriend. The couple had met in youth group during high school and became romantically involved a few years later. Their faith was a major source of bonding - they prayed on the phone, read scripture together, and attended church every Sunday. But many of Luke's peers were not religious and could not identify with the pace and priorities of Luke's relationship. Asked if he ever felt pressure to not get married quite so soon, Luke commented: "My roommates, I'm sure, think it's weird because they're not in steady relationships. It doesn't bother me".

Kelly, a 22-year-old white college student, wore a small engagement ring on her left hand. She and her fiancé, also a college student, had met on a mission trip abroad and quickly entered into a serious relationship

\footnotetext{
${ }^{3}$ Early marriage is much more common in the South and in relatively rural areas (McLaughlin et al., 1993; Uecker \& Stokes, 2008). Qualitative work on early marriage in a rural setting notes that this was "natural" and was not stigmatized (Kefalas et al., 2011).

${ }^{4}$ All names are pseudonyms.
} 
when they returned to the States. While Kelly was on her Christian college campus and was surrounded by coreligionists, her relationship status as engaged was not necessarily abnormal. But she was startled to see how very differently she approached relationships compared to her less religious confidants. She explained:

I have three really close friends, none of them are Christians...and so for them there's a little bit of this, like, 'You're so young, you have so much life. Like, what if you wanted to travel somewhere?' And even like explaining to them-even before we were engaged at all-being in a committed relationship, what [it] that was like-that was so bizarre to them.

These norms could also be jarring for Evangelicals who were relatively new to the subculture. Autumn, a 19-yearold white woman, had converted to Evangelical Christianity during high school and went on to attend a Christian college. When her boyfriend of a few months told Autumn that he loved her and wanted to marry her, she was taken aback. When she shared the seriousness of her new relationship with friends from home-who were not Evangelical-they considered it inappropriate for someone her age to be considering marriage. Autumn recalled:

My Christian friends at school...they're very much like, 'It's whenever you feel ready to get married, it doesn't matter how young or old you are'. But these past few weeks when I've been home and seeing old friends they're like, 'What? You're only 19. You should live your life!' And some of them are 24 or 25 years old but they don't see life the same way....They think that being in a six-month relationship, that's too committed.

Vincent, a 22-year-old white man, was also a relatively new Evangelical Christian. When we met, Vincent had just proposed to his girlfriend. While his closest friend was supportive of his marriage plans, Vincent describes many who disparaged his decision. He said:

Then you have our peers. People who aren't really close to us that sit there and be like, 'You got time to wait, man'. Then there's people who are like, 'Oh man, you're getting married. Like the old ball and chain'. We got mixed reviews from a lot of people.

Outside of peer groups, respondents also sometimes faced scrutiny of their marriage decisions from acquaintances or from complete strangers. Sometimes, people in occupational settings and in public judged them to be "too young" and felt free to comment on the incompatibility of their age and marital status. This seemed to happen particularly among women, perhaps because the visible signs of engagement and marriage (such as engagement rings).

For instance, Isobel was a 21-year-old Latina woman. She and her fiancé planned to marry in the upcoming summer. Isobel had received several notable instances of pushback at her workplace. She shared how a recent coworker was "weird" after he saw her engagement ring. Isobel explained:

At my job, there's this man that just got hired, and so I went up to him to go over a report or something and he saw my ring....and then he was like, 'If you don't mind me asking, why are you marrying so young?' It was so awkward.

Valerie, a 23-year-old white woman, also faced skepticism and implicit disapproval from coworkers. A recent college graduate, Valerie's new coworkers were perplexed by her marital status. She recounted: "But I can remember, like, coworkers or whatever being like, 'Oh, you're getting married? Like, you're engaged? How old are you?' I would get that question a lot".

Isobel and Valerie had passing knowledge of the persons who expressed surprise over their early marriages. Other women recounted absolute strangers in public spaces who noted their astonishment or explicit disapproval. Maya, a 23-year-old white woman, had been married two weeks when we met for an interview. Holding a master's degree from a Christian college, Maya was surrounded by many peers who wed shortly after graduation. While Maya's immediate social circle was supportive, she faced occasional pushback. The day after we met, Maya went to the Social Security office to change her last name. I received a text from Maya. She reported: "The lady from the Social Security office said I'm too young to be married! LOL".

Monica encountered more intense scrutiny. Married at 20, Monica described how she faced strong disapproval from strangers while celebrating her bachelorette party with some girlfriends. Because she was sporting a celebratory sash, people approached and asked if it was her birthday. When Monica responded that she was getting married, people were aghast. Monica recalled: "I mean, even just that night I got so many looks and comments, because [getting married at twenty is] not when people get married in society. Today it's in your thirties. So definitely got some looks".

Evangelicals who marry early or advance towards the altar at younger ages face considerable scrutiny and disapproval, most vocally from their secular friends. To a lesser degree, this disapproval is echoed by acquaintances or even in public settings by strangers. Marrying in the late teens or even the early twenties is not only statistically unusual but appears to be judged as mismatched with a larger script about emerging adulthood-as a life stage of exploration, freedom, and mobility.

\subsection{Middle Class Sensibilities and Early Marriage}

Respondents from both working- and middle-class backgrounds recounted secular disapproval of their early marital timelines. However, respondents in middle class cul- 
tural milieus faced additional stigmatization when their marriage-pathways conflicted with educational trajectories. In these cases, it was not their age or life stage, per se, that was the source of sanctioning but rather the ordering of these milestones. In particular, middle class sensibilities dictated the importance of achieving an educational foundation in the form of a bachelor's degree prior to marriage.

In practice, Evangelical romantic relationships were typically assumed to be headed towards marriage. This was supported by most religious peers and family members. In most cases, this would result in relatively early marital unions-or at least earlier than the secular norm. In fact, the handful of respondents who did not date during college expressed discomfort that they were not progressing on the appropriate timeline. Their families expected them to enter serious relationships and marry shortly after a bachelor's degree was acquired. Edward, a 25-year-old white man who only began a romantic relationship after graduating from college, described the model relationship pathway that was expected of him. He explained: "My older brother started dating freshman year of college. And so just that precedent was set, and he married very young. Like, he graduated from college in March 2012 when he was 21 and got married two months later".

Indeed, many other Evangelical young adults seemed to have internalized the bachelor's degree as an important baseline for marriage readiness. Paul, a 24-year-old white man, was a college graduate while his fiancé was finishing her senior year. Though Paul was already stably employed and had completed his education, he considered it unsuitable to tie the knot prior to his fiancé's college graduation. Thus, while Paul proposed while his fiancé was still a student, he had long ago decided that their wedding would be delayed until after she achieved this educational milestone. He stated:

I kind of made a goal where like if they're in school, I wasn't going to marry them, or they were going to wait 'til college is over. That was something I even said for myself, like I'm not going to get married when I'm in school.

The strength of this norm was perhaps most overtly expressed among the handful of respondents who broached the topic of getting married while still in college. In most cases, families were accepting of Evangelical young adults' personal decision to marry-but objected to the timeline when it conflicted with college graduation. It is important to note that these negative reactions occurred even within religious settings. Evangelical family members, and sometimes even religious schools, still preferred young adults to wait until after college graduation to tie the knot.

Casey, a 22-year-old white man proposed to his college girlfriend, Monica (described above) when both were aged 20. Before asking his future wife out on a date,
Casey met her father to ask for permission. As the relationship continued, Casey routinely spoke with his future father-in-law about the pace of their relationship and his plans for the future. When the couple began struggling to avoid sexual temptation, Casey decided they should get married sooner than later. Although Monica's father liked and approved of Casey, he was not pleased at the prospect of marriage in the midst of an undergraduate education. Casey explained:

Over the next four or five months he and I talked quite a bit. I kind of let him know, 'Hey, we would like to get married soon. Much sooner rather than later'. At first, he wasn't as excited about that. [He said,] 'Well, you know, why don't you wait two or three more years until you're both done with school?'

In the end, Casey was able to persuade his father-in-law and the couple wed in college. Others, however, postponed their wedding plans due to their family's disapproval. Caroline, a 23-year-old white woman, married her beau shortly after both had graduated from college. However, this was later than the couple initially hoped for. Chuckling, Caroline reflected on the intense scolding they would have received had they married while still in college. She said: "We had talked briefly about getting married before he finished or eloping my senior year. We did not elope my senior year. Would've been really maddening for both of our families".

Liam, a 25-year-old white man, likewise explained that his Evangelical family was supportive of his early marriage (at age 23) - but only because he had a bachelor's degree already. In retrospect, Liam is a bit frustrated by this. He explained,

My parents were all on board and excited [with my marriage], but I think it helped that I had graduated by that time.... d don't know. This is going beyond the bounds of question, but we got married young. I've turned into a bit of a defender of people getting married young....I think there's some kind of gut reactions that people have against people getting married before finishing college and those reasons are never fully explained. And when examined, they're not as thorough as people tend to think they are.

In addition, some respondents faced pushback from middle class influences outside their immediate families. In particular, some respondents reported strong reactions towards their marital timelines within educational settings.

Jamielynn, a 26-year-old white woman, married her husband when she was 20 . While Jamielynn's husband, who was two years older than her, was a recent college graduate at the time of their wedding, Jamielynn was still attending classes at a local community college. Earlier in the interview, she had reported her classmates' surprise when her purity ring was replaced by an engage- 
ment ring. But beyond the bewilderment of her peers, Jamielynn faced additional scrutiny by a college professor. She recounted the story, saying:

I had an art teacher at that season, this was actually the harshest and most critical conversation I had....After that class, he pulled me into the hallway and reprimanded me, like, pretty hardcore. It was like, 'You cannot be focusing on marriage right now. You are in college. You're an artist and you need to take that seriously'. I was a student in one of his classes. And he took it very personally and seriously. I remember just being really wowed by his passion for reprimanding me. I could tell he felt so dignified in what he was saying, like, 'I'm going to do this girl a favor and break off her engagement', that seemed to be his goal.

Jamielynn's experience with her professor occurred at a local community college. But this disapproval in educational settings was not confined to secular environments. Kenneth, a 22-year-old black male, married when he was 20 years old. He and his wife had met at Bible college, where Kenneth was pursuing a four-year degree. Even within this religious institution, Kenneth faced pushback at the prospect of marrying while still a college student. He said:

I felt pressure not to get married.... had an advisor, like an academic advisor, kind of like [say], 'Oh, you should focus on school', and all that stuff. Stuff like that, people say. I dunno. Not pressure but there was like a suggestion [of] getting married later kind of stuff.

In contrast, young adults who were not in middle class cultural environments did not face the same kind of skepticism about meeting various milestones prior to marriage. Patrick, a 26-year-old black man, wed his wife when both were 18. Patrick, a former truck driver and now Uber driver, excitedly shared his good news with anyone who would listen. In contrast, his wife kept their marriage a secret for near half a year before telling her family. Patrick was frustrated by this but understood his wife's reasoning. He explained:

She didn't want our relationship to be known until she was ready. She had wanted to keep us on the low-low as much as possible 'cause her dad and her mom was like, 'Finish school first, then get a boyfriend or whatever'. So, we tried to keep our relationship discrete. I'd say her sophomore year we finally told everybody that we [were] married or whatever.

Patrick did not attend college and his marriage was not perceived as impeding his progress. When he told his grandmother and other family members, he explained they were "happy about it" while his middle class in-laws were furious.
Likewise, Ben, a 28-year-old white upwardly mobile man who married at 24, can scarcely remember how his parents reacted to his young marriage because it was relatively commonplace within his family. After explaining that his parents had married at age 19 themselves, Ben said: "I don't really remember the reaction....The idea of getting married young, normal, not a problem-[My brother] got married at 24, my older brother".

While marriage is prized by their religious community, many Evangelicals still ascribe importance to acquiring middle class baselines prior to marriage. In particular, a bachelor's degree is considered an important milestone for marriage-readiness. Evangelical young adults typically describe wanting to wait until after college graduation to marry their significant others - and may face considerable pushback if they advance their relationship before earning a degree.

\section{Conclusion}

Evangelical young adults are in a bind. On the one hand, their religious background highly values marriage and family life. This stands in opposition to the wider secular narrative, which sees emerging adulthood as a period of exploration, freedom, and self-discovery. In addition, middle class cultural sensibilities idealize marriage but still presume baselines, particularly the acquisition of a bachelor's degree, prior to marriage.

Breaking these norms can bring exclusion and criticism to young adults who marry at young ages. The strong censoring of early marriage among respondents in this article may be of concern for the outcomes of young couples. Notably, perceived disapproval of romantic pairings lends itself to relationship dissolution (Felmlee, 2001; Lehmiller \& Agnew, 2006; Sprecher \& Felmlee, 1992) or negative health outcomes for one or both partners (Blair \& Holmberg, 2008). This disapproval is perhaps related to the higher rates of dissolution among early marriages (Booth \& Edwards, 1985; Lehrer, 1998; Raley \& Bumpass, 2003).

Although early married young adults are a minority, they are not an insignificant portion of the young adult population in the United States. While they likely differ from other young people in the trajectory of their romantic relationships, this article underscores the importance of the social context of couples' relationships. Notably, marriage is conceptualized not just by individuals themselves but also by the larger community. Young adults who diverge from secular relationship norms and middleclass trajectories are greeted with disapproval. Although most of my respondents were already married or were poised to be married at early ages, it is certainly possible that negative sanctioning disrupts or otherwise delays other unions.

Prior research indicates that the religious messages transmitted to young adults can help to reproduce the typically lower social class status of Evangelical Protestants, particularly through depressing the educational 
attainment of women (Fitzgerald \& Glass, 2008; Glass \& Jacobs, 2005; Glass, Sutton, \& Fitzgerald, 2015). My findings suggest that middle class Evangelicals are actually discouraged from marrying prior to receiving a bachelor's degree. This particular messaging-wherein marriage is promoted early enough to be distinct but still adheres to some degree of middle class norms so as not to be countercultural-may be an example of Evangelicals' successful subcultural identity (Smith, 1998).

\section{Acknowledgements}

The author thanks the Religious Research Association's support of this project through the Constant $\mathrm{H}$. Jacquet research award, and the University of Pennsylvania's Program for Research on Religion and Urban Civil Society.

\section{Conflict of Interests}

The author declares no conflict of interests.

\section{References}

Arnett, J. J. (1998). Learning to stand alone: The contemporary American transition to adulthood in cultural and historical context. Human Development, 41(5/6), 295-315. https://doi.org/10.1159/000022591

Arnett, J. J. (2006). Emerging adulthood: The winding road from the late teens through the twenties. New York, NY: Oxford University Press.

Arnett, J. J. (2016). Does emerging adulthood theory apply across social classes? National data on a persistent question. Emerging Adulthood, 4(4), 227-235. https://doi.org/10.1177/2167696815613000

Arnett, J. J., Kloep, M., Hendry, L. B., \& Tanner, J. L. (2010). Debating emerging adulthood: Stage or process? New York, NY: Oxford University Press.

Becker, G. S. (1993). A treatise on the family. Cambridge, MA: Harvard University Press.

Berzin, S. C., \& De Marco, A. C. (2010). Understanding the impact of poverty on critical events in emerging adulthood. Youth \& Society, 42(2), 278-300. https://doi.org/10.1177/0044118X09351909

Blair, K. L., \& Holmberg, D. (2008). Perceived social network support and well-being in same-sex versus mixed-sex romantic relationships. Journal of Social and Personal Relationships, 25(5), 769-791.

Bogle, K. A. (2008). Hooking up: Sex, dating, and relationships on campus. New York, NY: New York University Press.

Booth, A., \& Edwards, J. N. (1985). Age at marriage and marital instability. Journal of Marriage and Family, 47(1), 67-75.

Bramlett, M. D., \& Mosher, W. D. (2002). Cohabitation, marriage, divorce, and remarriage in the United States. Vital Health Statistics, 23(22), 1-93.

Carroll, J. S., Badger, S., Willoughby, B. J., Nelson, L. J., Madsen, S. D., \& Barry, C. M. (2009). Ready or not? Criteria for marriage readiness among emerging adults. Journal of Adolescent Research, 24(3), 349-375.

Cherlin, A. J. (2010a). Demographic trends in the United States: A review of research in the 2000s. Journal of Marriage and Family, 72(3), 403-419. https://doi.org/10.1111/j.1741-3737.2010.00710.x

Cherlin, A. J. (2010b). The marriage-go-round: The state of marriage and the family in America today. New York, NY: Vintage.

Claxton, S. E., \& van Dulmen, M. H. M. (2013). Casual sexual relationships and experiences in emerging adulthood. Emerging Adulthood, 1(2), 138-150. https://doi.org/10.1177/2167696813487181

Cohn, D., Passel, J. S., Wang, W., \& Livingston, G. (2011). New marriages down 5\% from 2009 to 2010: Barely half of U.S. adults are married-A record low. Washington, DC: Pew Research Center. Retrieved from http://assets.pewresearch.org/wp-content/ uploads/sites/3/2011/12/Marriage-Decline.pdf

Copen, C. E., Daniels, K., Vespa, J., \& Mosher, W. D. (2012). First marriages in the United States: Data from the 2006-2010 national survey of family growth (National Health Statistics Report No. 49). Hyattsville, MD: U.S. Department of Health and Human Services, Centers for Disease Control and Prevention, Division of Vital Statistics.

Côté, J. E. (2014). The dangerous myth of emerging adulthood: An evidence-based critique of a flawed developmental theory. Applied Developmental Science, 18(4), 177-188. https://doi.org/10.1080/ 10888691.2014.954451

Edin, K., \& Kefalas, M. J. (2005). Promises I can keep: Why poor women put motherhood before marriage. Berkeley, CA: University of California Press.

Erchull, M. J., Liss, M., Axelson, S. J., Staebell, S. E., \& Askari, S. F. (2010). Well...She wants it more: Perceptions of social norms about desires for marriage and children and anticipated chore participation. Psychology of Women Quarterly, 34(2), 253-260. Retrieved from http://proxy.library.upenn.edu:2169/ doi/abs/10.1111/j.1471-6402.2010.01566.x

Erikson, E. H. (1970). Reflections on the dissent of contemporary youth. Daedalus, 99(1), 154-176.

Erikson, E. H. (1998). The life cycle completed: Extended version. New York, NY: W. W. Norton \& Company.

Felmlee, D. H. (2001). No couple is an island: A social network perspective on dyadic stability. Social Forces, 79(4), 1259-1287. https://doi.org/10.1353/ sof.2001.0039

Fitzgerald, S. T., \& Glass, J. (2008). Can early family formation explain the lower educational attainment of U.S. conservative Protestants? Sociological Spectrum, 28(5), 556-577. https://doi.org/10.1080/ 02732170802206203

Furstenberg, F. F. (2008). The intersections of social class and the transition to adulthood. New Directions for Child and Adolescent Development, 2008(119), 1-10. 
https://doi.org/10.1002/cd.205

Glass, J., \& Fitzgerald, S. T. (2012). Conservative Protestants, early transitions to adulthood, and the intergenerational transmission of class. In L. A. Keister (Eds.), Religion, work and inequality (Vol. 23, pp. 49-72). Bingley: Emerald Group Publishing Limited. https://doi.org/10.1108/S0277-2833(2012) 0000023006

Glass, J., \& Jacobs, J. (2005). Childhood religious conservatism and adult attainment among black and white women. Social Forces, 84(1), 555-579. https:// doi.org/10.1353/sof.2005.0098

Glass, J. L., Sutton, A., \& Fitzgerald, S. T. (2015). Leaving the faith: How religious switching changes pathways to adulthood among conservative Protestant youth. Social Currents, 2(2), 126-143. https://doi.org/ $10.1177 / 2329496515579764$

Glenn, N. D., Uecker, J., \& Love, R. W. B. (2010). Later first marriage and marital success. Social Science Research, 39(5), 787-800. https://doi.org/10.1016/ j.ssresearch.2010.06.002

Goldstein, J. R., \& Kenney, C. T. (2001). Marriage delayed or marriage forgone? New cohort forecasts of first marriage for U.S. women. American Sociological Review, 66(4), 506-519. https://doi.org/10.2307/ 3088920

Hymowitz, K., Carroll, J. S., Wilcox, W. B., \& Kaye, K. (2013). Knot yet: The benefits and costs of delayed marriage in America. Charlottesville, VA: The National Marriage Project at the University of Virginia, The National Campaign to Prevent Teen and Unplanned Pregnancy and The Relate Institute. Retrieved from http://nationalmarriageproject.org/wpcontent/uploads/2013/03/KnotYet-FinalForWeb.pdf

Kalmijn, M. (1991). Shifting boundaries: Trends in religious and educational homogamy. American Sociological Review, 56(6), 786-800. https://doi.org/ $10.2307 / 2096256$

Kaufman, G. (2005). Gender role attitudes and college students' work and family expectations. Gender Issues, 22(2), 58-71. https://doi.org/10.1007/s12147005-0015-1

Kefalas, M. J., Furstenberg, F. F., Carr, P. J., \& Napolitano, L. (2011). "Marriage is more than being together": The meaning of marriage for young adults. Journal of Family Issues, 32(7), 845-875. https://doi.org/ 10.1177/0192513X10397277

Lareau, A. (2011). Unequal childhoods: Class, race, and family life (Second Edition). Berkeley: University of California Press.

Lehmiller, J. J., \& Agnew, C. R. (2006). Marginalized relationships: The impact of social disapproval on romantic relationship commitment. Personality and Social Psychology Bulletin, 32(1), 40-51.

Lehrer, E. L. (2008). Age at marriage and marital instability: Revisiting the Becker-Landes-Michael hypothesis. Journal of Population Economics, 21(2), 463-484. https://doi.org/10.1007/s00148-006-0092-9
Lehrer, E. L. (1998). Religious intermarriage in the United States: Determinants and trends. Social Science Research, 27(3), 245-263. https://doi.org/10.1006/ ssre.1998.0626

Maguire, M., Ball, S. J., \& MacRae, S. (2001). Postadolescence, dependence and the refusal of adulthood. Discourse: Studies in the Cultural Politics of Education, 22(2), 197-211. https://doi.org/10.1080/ 01596300124693

Martin, S. P. (2004). Women's education and family timing: Outcomes and trends associated with age at marriage and first birth. In K. M. Neckerman (Ed.), Social Inequality (pp. 79-118). New York, NY.: Russell Sage Foundation.

McClendon, D. (2016). Religion, marriage markets, and assortative mating in the United States. Journal of Marriage and Family, 78(5), 1399-1421. https:// doi.org/10.1111/jomf.12353

McLaughlin, D. K., Lichter, D. T., \& Johnston, G. M. (1993). Some women marry young: Transitions to first marriage in metropolitan and nonmetropolitan areas. Journal of Marriage and the Family, 55(4), 827-838. https://doi.org/10.2307/352765

Pew Research Center. (2014). Record share of Americans have never married: As values, economics and gender patterns have changed. Washington, DC.: Pew Research Center. Retrieved from http://www. pewsocialtrends.org/2014/09/24/chapter-1-publicviews-on-marriage/

Raley, R. K., \& Bumpass, L. L. (2003). The topography of the divorce plateau: Levels and trends in union stability in the United States after 1980. Demographic Research, 8(8), 245-260. https://doi.org/10.4054/ DemRes.2003.8.8

Raley, R. K., Crissey, S., \& Muller, C. (2007). Of sex and romance: Late adolescent relationships and young adult union formation. Journal of Marriage and Family, 69(5), 1210-1226. https://doi.org/10.1111/ j.1741-3737.2007.00442.x

Ranta, M., Dietrich, J., \& Salmela-Aro, K. (2014). Career and romantic relationship goals and concerns during emerging adulthood. Emerging Adulthood, 2(1), 17-26. https://doi.org/10.1177/2167696813515852

Rendon, J. J., Xu, X., Denton, M. L., \& Bartkowski, J. P. (2014). Religion and marriage timing: A replication and extension. Religions, 5(3), 834-851. https:// doi.org/10.3390/rel5030834

Richter, R. (1994). Post-adolescence as a new phase in the family cycle? Innovation: The European Journal of Social Science Research, 7(1), 63-68. https:// doi.org/10.1080/13511610.1994.9968387

Settersten, R. A., Furstenberg, F. F., \& Rumbaut, R. G. (2005). On the frontier of adulthood: Theory, research, and public policy. Chicago, IL: University of Chicago Press.

Silva, J. (2016). High hopes and hidden inequalities: How social class shapes pathways to adulthood. Emerging Adulthood, 4(4), 239-241. https://doi.org/10.1177/ 


\section{5}

Smith, C. (1998). American Evangelicalism: Embattled and thriving. Chicago, IL: University of Chicago Press.

Smith, C., \& Snell, P. (2009). Souls in transition: The religious and spiritual lives of emerging adults. New York, NY: Oxford University Press.

Smock, P. J., Manning, W. D., \& Porter, M. (2005). "Everything's there except money": How money shapes decisions to marry among cohabitors. Journal of Marriage and Family, 67(3), 680-696. https://doi.org/ 10.1111/j.1741-3737.2005.00162.x

Sprecher, S., \& Felmlee, D. (1992). The influence of parents and friends on the quality and stability of romantic relationships: A three-wave longitudinal investigation. Journal of Marriage and the Family, 54(4), 888-900. https://doi.org/10.2307/353170

Steensland, B., Park, J. Z., Regnerus, M. D., Robinson, L. D., Wilcox, W. B., \& Woodberry, R. D. (2000). The measure of American religion: Toward improving the state of the art. Social Forces, 79(1), 291-318.

Swartz, T. T. (2008). Family capital and the invisible transfer of privilege: Intergenerational support and social class in early adulthood. New Directions for Child and Adolescent Development, 2008(119), 11-24. https://doi.org/10.1002/cd.206

Sweeney, M. M. (2002). Two decades of family change: The shifting economic foundations of marriage. American Sociological Review, 67(1), 132-147.

Thornton, A. (1985). Reciprocal influences of family and religion in a changing world. Journal of Marriage and the Family, 47(2), 381-394. https://doi.org/10.2307/ 352138
Thornton, A., Axinn, W. G., \& Hill, D. H. (1992). Reciprocal effects of religiosity, cohabitation, and marriage. American Journal of Sociology, 98(3), 628-651. https://doi.org/10.1086/230051

Thornton, A., \& Young-DeMarco, L. (2001). Four decades of trends in attitudes toward family issues in the United States: The 1960s through the 1990s. Journal of Marriage and Family, 63(4), 1009-1037. https://doi.org/10.1111/j.1741-3737.2001.01009.x

Uecker, J. E. (2014). Religion and early marriage in the United States: Evidence from the Add Health study. Journal for the Scientific Study of Religion, 53(2), 392-415. https://doi.org/10.1111/jssr.12114

Uecker, J. E., \& Stokes, C. E. (2008). Early marriage in the United States. Journal of Marriage and Family, 70(4), 835-846. https://doi.org/10.1111/j.17413737.2008.00530.x

Willoughby, B. J., Carroll, J. S., Vitas, J. M., \& Hill, L. M. (2011). "When are you getting married?": The intergenerational transmission of attitudes regarding marital timing and marital importance. Journal of Family Issues, 0192513X11408695. https://doi.org/ $10.1177 / 0192513 \times 11408695$

Willoughby, B. J., \& Hall, S. S. (2015). Enthusiasts, delayers, and the ambiguous middle: Marital paradigms among emerging adults. Emerging Adulthood, 3(2), 123-135. https://doi.org/10.1177/ 2167696814548478

Xu, X., Hudspeth, C. D., \& Bartkowski, J. P. (2005). The timing of first marriage: Are there religious variations? Journal of Family Issues, 26(5), 584-618. https://doi.org/10.1177/0192513X04272398

\section{About the Author}

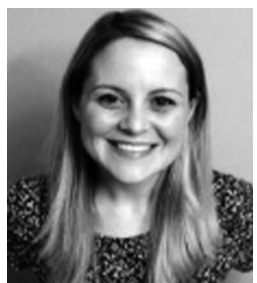

Patricia Tevington is a Doctoral Candidate in Sociology at the University of Pennsylvania. She received her bachelor's degree in Sociology from the College of New Jersey and her master's degree from the University of Pennsylvania. Her research interests include social class and inequality, sociology of religion, and sociology of the family. In particular, she studies how class and religious background affect the pathways of young people in their transition to adulthood. 